\section{Impact of Experimental Nano-HAP Pastes on Bovine Enamel and Dentin Submitted to a $\mathrm{pH}$ Cycling Model}

Livia P. Comar, Beatriz M. Souza, Luiz Fernando Gracindo, Marília A. R. Buzalaf, Ana Carolina Magalhães
Department of Biological Sciences, Bauru Dental School, USP - University of São Paulo, Bauru, SP, Brazil

Correspondence: Profa. Dra. Ana Carolina Magalhães, Alameda Octávio Pinheiro Brisolla, 9-75, 17012-901 Bauru, SP, Brasil. Tel. + 55-143235-8497. e-mail: acm@usp.br

\begin{abstract}
This in vitro study evaluated the preventive potential of experimental pastes containing $10 \%$ and $20 \%$ hydroxyapatite nanoparticles (Nano-HAP), with or without fluoride, on dental demineralization. Bovine enamel $(n=15)$ and root dentin $(n=15)$ specimens were divided into 9 groups according to their surface hardness: control (without treatment), 20 Nanop paste (20\% HAP), 20 Nanop paste plus (20\% HAP + 0.2\% NaF), 10 Nanop paste (10\% HAP), 10 Nanop paste plus (10\% HAP + 0.2\% NaF), placebo paste (without fluoride and HAP), fluoride paste $(0.2 \% \mathrm{NaF}), \mathrm{MI}$ paste (CPP-ACP, casein phosphopeptide-amorphous calcium phosphate), and $\mathrm{MI}$ paste plus (CPP-ACP $+0.2 \% \mathrm{NaF}$ ). Both $\mathrm{MI}$ pastes were included as commercial control products containing calcium phosphate. The specimens were treated with the pastes twice a day $(1 \mathrm{~min})$, before and after demineralization. The specimens were subjected to a $\mathrm{pH}$-cycling model (demineralization-6-8 $\mathrm{h} /$ remineralization-16-18 $\mathrm{h}$ a day) for 7 days. The dental subsurface demineralization was analyzed using cross-sectional hardness ( $\mathrm{kgf} / \mathrm{mm}^{2}$, depth 10-220 $\left.\mu \mathrm{m}\right)$. Data were tested using repeated-measures two-way ANOVA and Bonferroni's test $(p<0.05)$. The only treatment able to reduce the loss of enamel and dentin subsurface hardness was fluoride paste $(0.2 \% \mathrm{NaF})$, which differed significantly from the control at $30-$ and $50-\mu m$ depth $(p<0.0001)$. The other treatments were not different from each other or compared with the control. The experimental Nanop pastes, regardless of the addition of fluoride, were unable to reduce dental demineralization in vitro.
\end{abstract}

Key Words: casein phosphopeptide-amorphous calcium phosphate, demineralization, hydroxyapatite nanoparticles, remineralization.

\section{Introduction}

The decline in caries prevalence over the last 25 years has been attributed to the widespread use of fluoride (1). On the other hand, the evidence of an increasing prevalence of dental fluorosis (2) and some fluoride limitations, such as the inability to completely remineralize carious lesion $(2,3)$, have led to the search for alternative non-fluoride agents that could provide a complete prevention or arrest of dental caries lesion (4).

Nano-hydroxyapatite (Nano-HAP) is considered one of the most biocompatible and bioactive materials. It is widely applied in medicine and dentistry as a bone substitute and for tooth remineralization $(5,6)$. Evidence has demonstrated that nano-sized particles have similar morphology and crystal structure compared with dental apatite (7). Recent reports have shown that Nano-HAP has a good potential to remineralize enamel carious lesions $(4,6,8,9)$, but limited information is available regarding the prevention of demineralization, and on dentin lesions regression as well.

Alternatively, products containing other calcium phosphate salts, with a similar acting mechanism have also been tested. Pastes containing a complex of casein phosphopeptide (CPP) and amorphous calcium phosphate $(A C P)$, with or without fluoride, have shown potential to prevent dental demineralization, increase remineralization in vitro (10-14) and to repair initial enamel caries lesions in vivo as well (15-17). It has been suggested that casein phosphopeptides (CPP) have the ability to stabilize calcium phosphate in solution by binding amorphous calcium phosphate (ACP) with their multiple phosphoserine residues, thereby allowing the formation of small CPPACP clusters (18).

Considering the lack of studies testing the effect of Nano-HAP on the prevention of dental caries lesions and on dentin substrates, the purpose of this in vitro study was to assess the preventive potential of experimental pastes containing 10\% and 20\% hydroxyapatite nanoparticles (Nano-HAP), with or without fluoride, on enamel and dentin demineralization, comparing them to CPP-ACP pastes (commercial controls). The research hypothesis is that experimental Nano-HAP pastes have a better preventive effect compared with commercial pastes with CPP-ACP, and both are more effective than the control and placebo paste groups on dental demineralization in vitro.

\section{Material and Methods Preparation of Specimens}

One hundred thirty-five enamel and dentin specimens $(4 \mathrm{~mm} \times 4 \mathrm{~mm} \times 3 \mathrm{~mm}$ ) were prepared from the labial surface 
of the bovine crown and labial/lingual surfaces of the cervical portion of bovine roots, respectively. The teeth were stored in $0.1 \%$ buffered thymol solution (pH 7.0) at $4^{\circ} \mathrm{C}$. The specimens were cut using an ISOMET low-speed saw cutting machine (Buehler Ltd., Lake Bluff, IL, USA) with two diamond disks (Extec Corp., Enfield, CT, USA), separated by a 4-mm thick spacer. The specimens' surfaces were ground flat using water-cooled silicon carbide discs (320-, 600- and 1200-grit $\mathrm{Al}_{2} \mathrm{O}_{3}$ papers; Buehler), and polished using felt paper soaked with diamond solution (1 $\mu \mathrm{m}$; Buehler). After polishing, the specimens were cleaned in an ultrasonic bath with deionized water for $5 \mathrm{~min}$. The initial surface hardness was measured using the mean of five indentations (Knoop diamond, $25 \mathrm{~g} / 10 \mathrm{~s}$ for enamel and $10 \mathrm{~g} / 10 \mathrm{~s}$ for dentin) using a microhardness tester (HMV-2; Shimadzu Corporation, Tokyo, Japan).

Prior to the experiment, the specimens were covered with nail polish in order to create control areas on both sides of a central strip of enamel or dentin. The specimens were maintained in 100\% humidity until the beginning of

\begin{tabular}{|c|c|c|}
\hline Pastes & Calcium & Phosphate \\
\hline Placebo & 3.27 & 470.4 \\
\hline $\mathrm{F}$ & 1.66 & 380.2 \\
\hline 10 Nanop & 1.91 & 282.8 \\
\hline 10 Nanop plus & 2.09 & 256.8 \\
\hline 20 Nanop & 3.72 & 553.0 \\
\hline 20 Nanop plus & 3.57 & 424.8 \\
\hline Ml paste & 222.7 & 2249.3 \\
\hline Ml paste plus & 214.1 & 2616.8 \\
\hline
\end{tabular}

the experiment.

The 15 enamel and 15 dentin specimens were randomly allocated to one control (untreated) and 8 test groups according to their baseline surface hardness values $(328 \pm 18$ and $23 \pm 2 \mathrm{kgf} / \mathrm{mm}^{2}$ for enamel and dentin, respectively): 20 Nanop paste (20\% HAP), 20 Nanop paste plus (20\% HAP $+0.2 \% \mathrm{NaF}), 10$ Nanop paste (10\% HAP), 10 Nanop paste plus (10\% HAP+ 0.2\% NaF), placebo paste (without HAP and F), fluoride paste ( $0.2 \% \mathrm{NaF})$, MI paste (CPP-ACP), and $\mathrm{Ml}$ paste plus (CPP-ACP $+0.2 \% \mathrm{NaF}$ ). The Nanop-HAP pastes were prepared by FGM-Dentscare (Joinvile, SC, Brazil) and the MI paste products (Recaldent-CPP-ACP) were from GC America (St. Alsip, IL, USA). The experimental pastes (pH 7.0) contained nanometer calcium phosphate (hydroxyapatite, $100 \mathrm{~nm}$ ), sodium fluoride (in case of the plus pastes), potassium nitrate, distilled water, thickener, surfactant, moist, flavor, sweetener and preservative.

\section{Calcium and Phosphate Analysis}

The soluble calcium and phosphate contents of one representative paste of each group $(1 \mathrm{~g}$ paste $/ 5 \mathrm{~mL}$ deionized water centrifuged at $\times 5000$ for $10 \mathrm{~min}$ ) were evaluated using the colorimetric methods of Arsenazo III (19) and Fiske-Subarrow (20), respectively. Optical density measurements were carried out by a scanning spectrophotometer (Fluorstar Optima - BMG Labtech $\mathrm{GmbH}$, Ortenberg, Germany), at a $660 \mathrm{~nm}$ wavelength, in triplicate. The absorbance values were converted in $\mathrm{mg} \%$ using the standard curve with an $r \geq 0.99$.

\section{Treatment and $\mathrm{pH}$ Cycles}

Enamel specimens were subjected to a $\mathrm{pH}$-cycling model for 7 days, as described by Vieira et al. (21). For 5 days, the specimens were immersed in demineralizing solution [2.0 mmol/L Ca $\left(\mathrm{NO}_{3}\right)_{2} \cdot 4 \mathrm{H}_{2} \mathrm{O}, 2.0 \mathrm{mmol} / \mathrm{L} \mathrm{Na}{ }_{2} \mathrm{HPO}_{4} .2 \mathrm{H}_{2} \mathrm{O}, 75$ $\mathrm{mmol} / \mathrm{L}$ acetate buffer, $0.04 \mathrm{ppm} \mathrm{F}, \mathrm{pH} 4.7$ ] for $6 \mathrm{~h}(30 \mathrm{~mL}$

Table 2. Mean of enamel cross-sectional hardness and S.D. according to the treatment and depth $\left(\mathrm{kgf} / \mathrm{mm}^{2}\right)$

\begin{tabular}{|c|c|c|c|c|c|c|c|c|c|}
\hline Depth & 20 Nanop & $\begin{array}{l}20 \text { Nanop } \\
\text { plus }\end{array}$ & 10 Nanop & $\begin{array}{l}10 \text { Nanop } \\
\text { plus }\end{array}$ & Placebo & $\mathrm{F}$ & Ml Paste & $\begin{array}{l}\text { M1 Paste } \\
\text { Plus }\end{array}$ & Control \\
\hline $10 \mu \mathrm{m}$ & $3 \pm 6^{\mathrm{aA}}$ & $0 \pm 0^{\mathrm{aA}}$ & $1 \pm 4^{\mathrm{aA}}$ & $39 \pm 20^{\mathrm{aA}}$ & $1 \pm 3^{\mathrm{aA}}$ & $65 \pm 54^{\mathrm{aA}}$ & $3 \pm 7^{\mathrm{aA}}$ & $2 \pm 5^{\mathrm{aA}}$ & $7 \pm 10^{\mathrm{aA}}$ \\
\hline $30 \mu \mathrm{m}$ & $8 \pm 21^{\mathrm{aA}}$ & $0.2 \pm 0.7^{\mathrm{aA}}$ & $5 \pm 6^{\mathrm{aA}}$ & $54 \pm 27^{\mathrm{aAB}}$ & $2 \pm 5^{\mathrm{aB}}$ & $186 \pm 51^{\mathrm{bAB}}$ & $7 \pm 11^{\mathrm{aA}}$ & $4 \pm 8^{\mathrm{aA}}$ & $16 \pm 24^{\mathrm{aA}}$ \\
\hline $50 \mu \mathrm{m}$ & $37 \pm 63^{\mathrm{abA}}$ & $17 \pm 37^{\mathrm{aA}}$ & $40 \pm 34^{\mathrm{abA}}$ & $115 \pm 88^{\mathrm{bB}}$ & $16 \pm 30^{\mathrm{aAB}}$ & $253 \pm 49^{\mathrm{cBC}}$ & $39 \pm 46^{\mathrm{abA}}$ & $22 \pm 26^{\mathrm{aAB}}$ & $91 \pm 89^{a b B}$ \\
\hline $70 \mu \mathrm{m}$ & $133 \pm 109^{a b B}$ & $100 \pm 90^{\mathrm{abB}}$ & $127 \pm 104^{\mathrm{abB}}$ & $223 \pm 92^{\mathrm{cdc}}$ & $91 \pm 84^{\mathrm{aC}}$ & $243 \pm 53^{d C}$ & $144 \pm 81^{\mathrm{bcB}}$ & $85 \pm 69^{a b B}$ & $169 \pm 104^{\mathrm{abcdc}}$ \\
\hline $90 \mu \mathrm{m}$ & $228 \pm 129^{a c}$ & $240 \pm 78^{\mathrm{ac}}$ & $223 \pm 121^{\mathrm{ac}}$ & $272 \pm 71^{\mathrm{aCD}}$ & $224 \pm 84^{\mathrm{aD}}$ & $258 \pm 46^{\mathrm{ac}}$ & $262 \pm 49^{\mathrm{ac}}$ & $207 \pm 102^{\mathrm{ac}}$ & $226 \pm 71^{\mathrm{aD}}$ \\
\hline $110 \mu \mathrm{m}$ & $268 \pm 110^{\mathrm{aCD}}$ & $283 \pm 56^{\mathrm{aCD}}$ & $274 \pm 111^{\mathrm{aC}}$ & $292 \pm 57^{\mathrm{aD}}$ & $265 \pm 71^{\mathrm{aD}}$ & $267 \pm 43^{\mathrm{ac}}$ & $292 \pm 38^{\mathrm{aC}}$ & $248 \pm 79^{\mathrm{aCD}}$ & $261 \pm 52^{\mathrm{aD}}$ \\
\hline $200 \mu \mathrm{m}$ & $317 \pm 63^{\mathrm{aD}}$ & $319 \pm 53^{\mathrm{aD}}$ & $286 \pm 95^{\mathrm{ac}}$ & $306 \pm 56^{\mathrm{aD}}$ & $275 \pm 42^{\mathrm{aD}}$ & $258 \pm 49^{\mathrm{ac}}$ & $284 \pm 40^{\mathrm{aC}}$ & $283 \pm 57^{\mathrm{aD}}$ & $258 \pm 61^{\mathrm{aD}}$ \\
\hline
\end{tabular}

Treatments whose means are followed by distinct lowercase letters in the same row differ significantly $(\mathrm{p}<0.0001)$. Depths whose means are followed by distinct uppercase letters in the same column differ significantly $(p<0.0001)$. 
per specimen) and in remineralizing solution [1.5 $\mathrm{mmol} / \mathrm{L}$ $\mathrm{Ca}\left(\mathrm{NO}_{3}\right)_{2} .4 \mathrm{H}_{2} \mathrm{O}, 0.9 \mathrm{mmol} / \mathrm{L} \mathrm{Na}_{2} \mathrm{HPO}_{4} \cdot 2 \mathrm{H}_{2} \mathrm{O}, 150 \mathrm{mmol} / \mathrm{L} \mathrm{KCl}$, $0.02 \mathrm{~mol} / \mathrm{L}$ Tris buffer, $0.05 \mathrm{ppm} \mathrm{F}, \mathrm{pH} 7.0]$ for $18 \mathrm{~h}(30 \mathrm{~mL}$ per specimen) at $37^{\circ} \mathrm{C}$, without agitation. In the last two days, the specimens were maintained in remineralizing solution only. The solutions were replaced daily.

Dentin specimens were subjected to a $\mathrm{pH}$-cycling model for seven days $(3,22)$. The specimens were immersed in demineralizing solution $\left[1.5 \mathrm{mmol} / \mathrm{L} \mathrm{CaCl}_{2}, 0.9 \mathrm{mmol} / \mathrm{L}\right.$ $\mathrm{KH}_{2} \mathrm{PO}_{4}, 50 \mathrm{mmol} / \mathrm{L}$ lactic buffer, $\mathrm{pH}$ 5.0] for $8 \mathrm{~h}(30 \mathrm{~mL}$ per specimen) (3), and in remineralizing solution $[1.5 \mathrm{mmol} / \mathrm{L}$ $\mathrm{CaCl}_{2}, 0.9 \mathrm{mmol} / \mathrm{L} \mathrm{KH}_{2} \mathrm{PO}_{4}, 130 \mathrm{mmol} / \mathrm{L} \mathrm{KCl}, 20 \mathrm{mmol} / \mathrm{L}$ Hepes buffer, $5 \mathrm{mmol} / \mathrm{L} \mathrm{NaN}_{3}$, pH 7.0] for $16 \mathrm{~h}$ (30 mL per specimen) (22) at $37^{\circ} \mathrm{C}$ without agitation. The solutions were replaced daily.

The pastes were applied twice a day, before and after the demineralizing process, using a microbrush for $1 \mathrm{~min}$, to simulate the daily application. The excess paste was removed and the specimens were washed in deionized water for $5 \mathrm{~s}$ before being immersed in the de- or remineralizing solution.

\section{Hardness Determination}

Initially, enamel and dentin surface hardness was measured as described above (Knoop diamond, HMV-2; Shimadzu Corporation). Five indentations $100 \mu \mathrm{m}$ from each other, were made in the center of dental surface for selection and random distribution of the specimens in the groups. After the treatment and $\mathrm{pH}$-cycles, the crosssectional hardness (CSH) was measured. The specimens were longitudinally sectioned through the center, embedded in acrylic resin, and polished. Three rows of seven indentations each were made, one at the central region of the exposed enamel and dentin area and the other two $100 \mu \mathrm{m}$ below and above this, for $10 \mathrm{~s}$ under a $25 \mathrm{~g}$ and $10 \mathrm{~g}$ load, respectively. The indentations were made at 10, 30, 50, 70, 90,110 , and $220 \mu \mathrm{m}$ from the outer enamel and dentin surface. The mean values of all three measuring points at each distance from the surface were then averaged (kgf) $\mathrm{mm}^{2}$ ).

\section{Statistical Analysis}

The GraphPad InStat version 2.0 for Windows software (GraphPad Software, Inc., La Jolla, CA, USA) was used. The assumptions of equality of variances and normal distribution of data were checked for all the tested variables, using the Bartlett and Kolmogorov-Smirnov tests, respectively. Repeated-measures two-way ANOVA followed by Bonferroni's test were carried out, considering as criteria the treatments and the depths (Graph Pad Prism 4 software; GraphPad Software, Inc.). The significance level was set at $5 \%(n=15)$.

\section{Results}

Calcium and phosphate contents of the pastes are displayed in Table 1. The experimental Nanop paste contained low soluble calcium and phosphate, while the commercial MI pastes presented high level of soluble calcium and phosphate.

There were significant differences among the treatments, depths, and interaction between the factors for enamel ( $p<0.0001$ for all, Table 2). The experimental 20 and 10 Nanop pastes were unable to reduce the subsurface enamel demineralization. $\mathrm{F}$ paste significantly decreased the loss of enamel hardness at 30 and $50 \mu \mathrm{m}$ compared with control, and from 30 to $70 \mu \mathrm{m}$ compared with placebo. The 10 Nanop plus paste also significantly differed from placebo paste at 50 and $70 \mu \mathrm{m}$ depths. At the other depths and among the other treatments there were no significant differences (Table 2). Furthermore, there was a significant increase in the hardness values with the increase of enamel depth. For the 10 Nanop, 10 Nanop plus, placebo, MI paste and control, the hardness values increased significantly up

Table 3. Mean of dentin cross-sectional hardness and S.D. according to the treatment and depth $\left(\mathrm{kgf} / \mathrm{mm}^{2}\right)$

\begin{tabular}{|c|c|c|c|c|c|c|c|c|c|}
\hline Depth & 20 Nanop & $\begin{array}{c}20 \text { Nanop } \\
\text { plus }\end{array}$ & 10 Nanop & $\begin{array}{l}10 \text { Nanop } \\
\text { plus }\end{array}$ & Placebo & $\mathrm{F}$ & Ml Paste & $\begin{array}{l}\text { Ml Paste } \\
\text { Plus }\end{array}$ & Control \\
\hline $10 \mu \mathrm{m}$ & $0 \pm 0^{\mathrm{aA}}$ & $0.4 \pm 1.7^{\mathrm{aA}}$ & $0 \pm 0^{\mathrm{aA}}$ & $0 \pm 0^{\mathrm{aA}}$ & $0.5 \pm 2.1^{\mathrm{aA}}$ & $2.0 \pm 4.5^{\mathrm{aA}}$ & $0 \pm 0^{\mathrm{aA}}$ & $0 \pm 0^{\mathrm{aA}}$ & $0 \pm 0^{\mathrm{aA}}$ \\
\hline $30 \mu \mathrm{m}$ & $1.4 \pm 3.0^{\mathrm{aA}}$ & $1.6 \pm 3.3^{\mathrm{aA}}$ & $2.5 \pm 3.3^{\mathrm{aAB}}$ & $4.1 \pm 4.2^{\mathrm{abB}}$ & $2.1 \pm 3.7^{\mathrm{aA}}$ & $6.7 \pm 5.8^{\mathrm{bB}}$ & $1.0 \pm 2.6^{\mathrm{aA}}$ & $1.0 \pm 2.8^{\mathrm{aAB}}$ & $1.2 \pm 3.3^{\mathrm{aAB}}$ \\
\hline $50 \mu \mathrm{m}$ & $6.5 \pm 2.9^{\mathrm{abcB}}$ & $5.7 \pm 3.2^{\mathrm{aB}}$ & $5.6 \pm 4.4^{\mathrm{aB}}$ & $7.1 \pm 4.2^{\mathrm{bcB}}$ & $6.1 \pm 4.1^{\mathrm{abcB}}$ & $9.9 \pm 4.8^{c c}$ & $5.8 \pm 5.1^{\mathrm{aB}}$ & $3.2 \pm 4.0^{\mathrm{aB}}$ & $4.9 \pm 4.6^{\mathrm{aB}}$ \\
\hline $90 \mu \mathrm{m}$ & $9.2 \pm 3.1^{\mathrm{aBC}}$ & $9.2 \pm 2.9^{\mathrm{aBC}}$ & $11.1 \pm 3.8^{\mathrm{aBC}}$ & $12.2 \pm 3.3^{\mathrm{aCD}}$ & $10.5 \pm 3.5^{\mathrm{aBC}}$ & $11.0 \pm 5.3^{\mathrm{aC}}$ & $12.7 \pm 4.2^{\mathrm{aC}}$ & $10.5 \pm 4.4^{\mathrm{aC}}$ & $10.5 \pm 3.2^{\mathrm{aC}}$ \\
\hline $110 \mu \mathrm{m}$ & $11.6 \pm 2.6^{\mathrm{aCD}}$ & $11.4 \pm 3.5^{\mathrm{aCD}}$ & $12.7 \pm 4.0^{\mathrm{aC}}$ & $14.5 \pm 4.8^{\mathrm{aDE}}$ & $12.4 \pm 4.6^{\mathrm{aCD}}$ & $11.6 \pm 5.1^{\mathrm{aC}}$ & $14.6 \pm 4.6^{\mathrm{aCD}}$ & $13.0 \pm 4.0^{\mathrm{aCD}}$ & $12.3 \pm 3.1^{\mathrm{aCD}}$ \\
\hline $220 \mu \mathrm{m}$ & $12.3 \pm 3.5^{\mathrm{aD}}$ & $12.5 \pm 4.4^{\mathrm{abD}}$ & $14.0 \pm 5.3^{\mathrm{abc}}$ & $15.4 \pm 4.9^{\mathrm{abE}}$ & $13.7 \pm 6.2^{\mathrm{abD}}$ & $11.9 \pm 5.1^{\mathrm{aC}}$ & $16.4 \pm 5.8^{\mathrm{bD}}$ & $14.8 \pm 6.1^{\mathrm{abD}}$ & $15.1 \pm 4.2^{\mathrm{abD}}$ \\
\hline
\end{tabular}

Treatments whose means are followed by distinct lowercase letters in the same row differ significantly $(p<0.0001)$. Depths whose means are followed by distinct uppercase letters in the same column differ significantly $(p<0.0001)$. 
to $90 \mu \mathrm{m}$; for the $\mathrm{F}$ paste up to $50 \mu \mathrm{m}$ (the most superficial lesion); and for 20 Nanop, 20 Nanop plus, and MI paste plus up to $110 \mu \mathrm{m}$ depth (the deepest lesion) (Table 2).

As to dentin demineralization, there were significant differences among the treatments and the depths $(p<0.0001)$ and no interactions between the factors $(p=0.054)$ (Table 3). The F paste was the only treatment able to reduce the subsurface dentin demineralization compared with the control at 30 and $50 \mu \mathrm{m}$ and to the placebo paste at the $30-\mu \mathrm{m}$ depth. At the other depths and among the other treatments there were no significant differences. Hardness values increased with the increase of the dentin depth. For the 10 Nanop paste, the hardness values significantly increased up to $90 \mu \mathrm{m}$, and for the F paste up to a $50-\mu \mathrm{m}$ depth (the most superficial lesion). For the other treatments, the hardness values changed significantly up to a $110-\mu \mathrm{m}$ depth (the deepest lesion) (Table 3).

\section{Discussion}

The present study analyzed the effect of a new product on the prevention of dental demineralization. Currently, there is lack of knowledge about the remineralizing and desensitizing potential of biomaterials based on s nanotechnology, which, in turn, may be an important preventive strategy to be applied in high-caries risk patients.

The $\mathrm{pH}$-cycling model chosen for enamel and dentin was based on previous studies each focusing on one type of dental substrate $(3,21,22)$. The models should be able to simulate the demineralizing and remineralizing episodes, considering the composition of the different dental substrates, in order to create a subsurface mineral loss and not an erosive lesion (10 $\mu \mathrm{m}$ deep) at the end of the experiment. It is important to clarify that the design of the present study was not focused on showing the impact of the experimental pastes on the remineralization of pre-formed enamel and dentin caries lesions, but on the prevention of demineralization.

Another important aspect is that the experimental pastes are not dentifrices that should be diluted and applied during toothbrushing; the experimental pastes present the same mode of application as the commercial MI pastes, which must be applied after oral hygiene by the patient, using finger on the affected tooth areas (23). Therefore, in the present study all pastes were applied using a microbrush applicator for $1 \mathrm{~min}$. The cross-sectional hardness was chosen as a response variable, as it reflects the mechanical resilience of the hard tooth tissue, which might be indirectly related to its mineral content.

Accordingly, all pastes with calcium phosphate were unable to reduce the dental demineralization using this model, regardless of the type of compound (CPP-ACP or Nano-HAP) and dental substrate. Therefore, the tested hypothesis was rejected.

It was expect that the Nanop, which presents hydroxyapatite particles with characteristics similar to the dental apatite, would have the ability to provide calcium and phosphate in an adequate concentration and velocity to react with the dental structure (8), repairing or promoting the dental crystal growth (24).

In respect to remineralization, a previous study (9) showed that different concentrations of Nano-HAP (1, 5,10 , and $15 \%$ ) were effective compared with placebo on enamel remineralization, with 10\% HAP nanoparticles being the best concentration. The effect of $20-24 \%$ Nano-HAP on dentin remineralization was also similar to enamel in another study (6). It has been suggested that Nano-HAP leads to more mineral deposits on the outer layer than in the body lesion. Therefore, mineral diffusion could be inhibited by the highly mineralized surface layer, making full remineralization not achieved by application of Nano-HAP $(4,8)$. This phenomenon has been previously discussed; initial caries lesions can be rehardened by the deposition of hydroxyapatite that first happens near the surface layer, but then it is gradually transferred inward and finally precipitated in the dark zone during the longterm remineralization. From this perspective, Nano-HAP might have a good potential to promote remineralization (9) with regular daily use as proposed by the previous studies $(6,9)$. However, the present study was focused on demineralization, showing that the regular application of Nanop-HAP pastes was unable to prevent demineralization regardless of the Nanop-HAP concentration and the lesion depth. Additionally, the experimental pastes presented low calcium and phosphate content in water that might be related to its low solubility. Therefore, the experimental pastes could not react appropriately with the tooth. Another possible mechanism of action of the Nano-HAP would be a mechanical imbrication of the pastes into the porous dental surface due to the size of the particles; but regardless of this, the experimental pastes were ineffective to reduce demineralization.

Since previous studies have shown a positive effect of Nano-HAP on enamel and dentin remineralization $(4,6,8,9)$, there might be a different result if a $\mathrm{pH}$-cycling model focusing on the remineralization of pre-formed lesions (remineralization $>>>>$ demineralization) rather than demineralization (remineralization $>>$ demineralizati on) had been performed. The remineralizing potential of the experimental pastes (Nanop-HAP) on pre-demineralized hard dental tissue should be tested in future assays.

The addition of fluoride did not have any positive influence on the effect of the experimental Nanop-HAP pastes for both enamel and dentin. In vitro experimental conditions cannot encapsulate all the complexities of a 
living oral cariogenic environment (23). Therefore, in further studies, the effect of the experimental pastes must be tested in situ to show whether the reaction between Nanop or Nanop plus and the dental surface would be better in the presence of human saliva and acquired pellicle. In addition, it would be interesting to check if the effect might also be modulated by the time of application and the procedure to remove the pastes from the dental surface. The amount of product retained on the dental substrate after water washing in this in vitro model could be not enough to have any effect against demineralization; while in the presence of human saliva the results might be different.

On the other hand, the only treatment able to reduce the dental subsurface demineralization was $F$ paste, which lost its positive effect when incorporated into Nanop paste. Such result may be attributed to a possible reaction between $\mathrm{NaF}$ and HAP, reducing the quantity of soluble fluoride. The constant presence of low fluoride concentration in the oral fluids during an acidic challenge favors its absorption to the surface of the apatite crystals, inhibiting demineralization. When the $\mathrm{pH}$ is reestablished, traces of fluoride in oral fluid will make it highly supersaturated with respect to fluorhydroxyapatite, which will speed up the process of remineralization (25). Further studies should be performed to test the remineralizing effect and the dentin obliteration potential of the experimental $F$ paste.

Prospec MI pastes (CPP-ACP, with or without F) were included in the study as commercial controls, since they present a similar mechanism of action and application mode of the Nanop pastes. CPP-ACP products have shown an ability to prevent dental demineralization and increase remineralization of enamel and dentin in vitro $(12,13)$, as well as to arrest initial enamel caries lesions in vivo (15-17). However, due to the lack of clinical trials, there is no consensus about the cariostatic effect of CPP-ACP. The present study shows lack of a CPP-ACP effect on the prevention of dental demineralization, in spite of the commercial pastes presenting high level of soluble calcium and phosphate. Further studies using different protocols should be performed to confirm the present results, which might be explained at least partially by the $\mathrm{pH}$-cycling models. In conclusion, the experimental Nanop pastes, regardless of the concentration and presence of fluoride, were unable to reduce enamel and dentin demineralization under this in vitro protocol. Fluoride paste is still the best option to reduce dental demineralization in vitro.

\section{Resumo}

Este estudo in vitro avaliou o potencial de pastas experimentais contendo nanopartículas de hidroxiapatita a $10 \%$ e $20 \%$ (Nano-HAP), com ou sem fluoreto, na prevenção da desmineralização dentária. Espécimes de esmalte $(n=15)$ e de dentina radicular $(n=15)$ bovinos foram divididos em nove grupos de acordo com o valor de dureza superficial: controle (sem tratamento), pasta Nanop 20 (HAP 20\%), pasta Nanop 20 plus (HAP $20 \%+\mathrm{NaF} 0,2 \%$ ), pasta Nanop 10 (HAP 10\%), pasta Nanop 10 plus (HAP $10 \%+\mathrm{NaF} 0,2 \%$ ), pasta placebo (sem F e HAP), pasta fluoretada ( $\mathrm{NaF}$ $0,2 \%$ ), pasta MI (CPP-ACP, fosfopeptídio da caseína-fosfato de cálcio amorfo), e pasta MI plus (CPP-ACP + NaF 0,2\%). As duas pastas $\mathrm{Ml}$ foram inclusas como grupos controles comerciais contendo fosfato de cálcio. $0 \mathrm{~s}$ espécimes foram tratados com as pastas duas vezes ao dia (1 min), antes e após a desmineralização. Os espécimes foram submetidos a um modelo de ciclagem de $\mathrm{pH}$ (desmineralização 6-8 h/ remineralização 16-18 h por dia) durante sete dias. A desmineralização dentária de subsuperfície foi avaliada através da dureza longitudinal $\left(\mathrm{kgf} / \mathrm{mm}^{2}\right.$, profundidade de $10-220$ $\mu \mathrm{m})$. Os dados foram analisados utilizando ANOVA a dois critérios e teste de Bonferroni $(p<0,05)$. 0 único tratamento capaz de reduzir a perda da dureza de subsuperficie do esmalte e da dentina foi a pasta fluoretada ( $\mathrm{NaF}$ $0,2 \%)$, a qual diferiu significativamente do controle nas profundidades de 30 e $50 \mu \mathrm{m}$ da superfície $(p<0,0001)$. Os outros tratamentos não foram diferentes entre si ou quando comparados ao controle. As pastas experimentais Nanop, independentemente da presença de fluoreto, não foram capazes de reduzir a desmineralização dentária in vitro.

\section{Acknowledgements}

The authors would like to thank FAPESP (Proc. 2009/08518-3 and 2010/07001-4) for its financial support.

\section{References}

1. Brambilla E. Fluoride - is it capable of fighting old and new dental diseases? An overview of existing fluoride compounds and their clinical applications. Caries Res 2001;35 Suppl 1:6-9.

2. Buzalaf MA, Levy SM. Fluoride intake of children: considerations for dental caries and dental fluorosis. Monogr Oral Sci 2011;22:1-19.

3. Lagerweij MD, ten Cate JM. Acid susceptibility at various depths of pH-cycled enamel and dentine specimens. Caries Res 2006;40:33-37.

4. Huang S, Gao S, Cheng $L, Y u$ H. Combined effects of nano hydroxyapatite and Galla chinensis on remineralisation of initial enamel lesion in vitro. J Dent 2010;38:811-819.

5. Hanning $M$, Hanning $C$. Nanomaterials in preventive dentistry. Nat Nanotechnol 2010;5:565-569.

6. Tschoppe P, Zandim DL, Martus P, Kielbassa AM. Enamel and dentine remineralization by nano-hydroxyapatite toothpastes. J Dent 2011;39:430-437.

7. Vandiver J, Dean D, Patel N, Bonfield W, Ortiz C. Nanoscale variation in surface charge of synthetic hydroxyapatite detected by chemically and spatially specific high-resolution force spectroscopy. Biomaterials 2005;26:271-283.

8. Huang S, Gao S, Cheng L, Yu H. Remineralization potential of nanohydroxyapatite on initial enamel lesions: an in vitro study. Caries Res 2011;45:460-468.

9. Huang SB, Gao SS, Yu HY. Effect of nano-hydroxyapatite concentration on remineralization of initial enamel lesion in vitro. Biomed Mater 2009;4:034104.

10. Yamaguchi $K$, Miyazaki $M$, Takamizawa $T$, Inage $H$, Kurokawa $H$. Ultrasonic determination of the effect of casein phosphopeptideamorphous calcium phosphate paste on the demineralization of bovine dentin. Caries Res 2007;41:204-207.

11. Rahiotis C, Vougiouklakis G. Effect of a CPP-ACP agent on the demineralization and remineralization of dentin in vitro. J Dent 2007;35:695-698

12. Kumar VLN, Itthagarun A, King NM. The effect of casein phosphopeptide-amorphous calcium phosphate on remineralization of artificial caries-like lesions: an in vitro study. Aust Dent J 2008;53:3440.

13. Pulido MT, Wefel JS, Hernandez MM, Denehy GE, Guzman-Armstrong $\mathrm{S}$, Chalmers JM, et al.. The inhibitory effect of MI paste, fluoride and a combination of both on the progression of artificial caries-like lesions 
in enamel. Oper Dent 2008:33:550-555

14. Zhang Q, Zou J, Yang R, Zhou X. Remineralization effects of casein phosphopeptide-amorphous calcium phosphate crème on artificial early enamel lesions of primary teeth. Int J Paediatr Dent 2011;21:374381.

15. Yengopal V, Mickenautsch S. Caries preventive effect of casein phosphopeptide-amorphous calcium phosphate (CPP-ACP): a metaanalysis. Acta Odontol Scand 2009;67:321-332.

16. Morgan MV, Adams GG, Bailey DL, Tsao CE, Fischman SL, Reynolds $\mathrm{EC}$. The anticariogenic effect of sugar-free gum containing CPP-ACP nanocomplexes on approximal caries determined using digital bitewing radiography. Caries Res 2008;42:171-184.

17. Bailey DL, Adams GG, Tsao CE, Hyslop A, Escobar K, Manton DJ, et al.. Regression of post-orthodontic lesions by a remineralizing cream. J Dent Res 2009:88:1148-1153.

18. Reynolds EC. Remineralization of enamel subsurface lesions by casein phosphopeptide stabilized calcium phosphate solutions. J Dent Res 1997;76:1587-1595.

19. Smith HG Jr, Bauer PJ. Light-induced permeability changes in sonicated bovine disks: arsenazo III and flow system measurements. Biochemistry 1979;18:5067-5073.
20. Fiske $\mathrm{CH}$, Subbarow $\mathrm{Y}$. The colorimetric determination of phosphorus. J Biol Chem 1925;66:375-400.

21. Vieira AEM, Delbem ACB, Sassaki KT, Rodrigues E, Cury JA, Cunha RF. Fluoride dose response in $\mathrm{pH}$-cycling models using bovine enamel. Caries Res 2005;39:514-520

22. ten Cate JM, Arends J. Remineralization of artificial enamel lesions in vitro. II. Determination of activation energy and reaction order. Caries Res 1978;12:213-222.

23. Behnan SM, Arruda AO, González-Cabezas C, Sohn W, Peters MC. Invitro evaluation of various treatments to prevent demineralization next to orthodontic brackets. Am J Orthod Dentofacial Orthop 2010;138:712e1-7.

24. Cochrane NJ, Cai F, Huq NL, Burrow MF, Reynolds EC. New approaches to enhanced remineralization of tooth enamel. J Dent Res 2010;89:11871197.

25. Buzalaf MA, Pessan JP, Honório HM, ten Cate JM. Mechanisms of action of fluoride for caries control. Monogr Oral Sci 2011;22:97-114.

Received February 1, 2013 Accepted May 6, 2013 